South Asia Multidisciplinary Academic Journal

$7 \mid 2013$

The Ethics of Self-Making in Postcolonial India

Introduction. Selves and Society in Postcolonial India

Uday Chandra and Atreyee Majumder

\title{
OpenEdition
}

Journals

Electronic version

URL: http://journals.openedition.org/samaj/3631

DOI: 10.4000/samaj.3631

ISSN: 1960-6060

Publisher

Association pour la recherche sur l'Asie du Sud (ARAS)

Electronic reference

Uday Chandra and Atreyee Majumder, « Introduction. Selves and Society in Postcolonial India », South Asia Multidisciplinary Academic Journal [Online], 7 | 2013, Online since 15 October 2013, connection on 01 May 2019. URL : http://journals.openedition.org/samaj/3631 ; DOI : 10.4000/samaj.3631

This text was automatically generated on 1 May 2019.

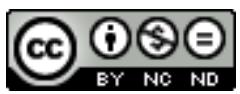

This work is licensed under a Creative Commons Attribution-NonCommercial-NoDerivatives 4.0 International License. 


\title{
Introduction. Selves and Society in Postcolonial India
}

\author{
Uday Chandra and Atreyee Majumder
}

1 On 16 December 2012, a twenty-three year old physiotherapist was gangraped in Munirka, New Delhi by six men in a bus. Thirteen days later, she passed away in Singapore, having suffered serious brain and gastrointestinal injuries. This case snowballed into a nationwide wave of protests on not only the heinousness of this particular incident, but the widespread public patriarchy that afflicts the right of Indian women to freely access public domains. On the days following her death, angry mobs and teargassing police clashed at India Gate in New Delhi. Multiple social imaginaries around gender, public sphere, state-responsibility and civicness collided. Some defended the victim as their mother or sister, who could potentially have been in that same situation. Others disagreed fervently, and invoked the modern female citizen, whose rights to dignity, safety and security mandated defense without recasting her as the fragile beneficiary of patriarchal protection. The RSS chief, Mohan Bhagwat, analyzed the situation as telling of crucial Indian cultural divide-'Such crimes hardly take place in 'Bharat', but they occur frequently in 'India' (Times of India 2013). The India-Bharat divide was refashioned in this moment, as the product of conflict between the postliberalization onslaught of transnational capital flows and the resilience of 'traditional' communitarian social structures. Moreover, a vast, cacophonous, polarized democratic field revealed itself in the aftermath of the December 16 rape. A variegated collective, comprising feminists, college-student liberals, right-wing patriarchs, and cynics, inhabited this cacophonous stage and its virtual counterpart. Just as the stage for $19^{\text {th }}$ century social reform came to pivot itself around the figure of the sati (Mani 1998), a number of political selves crystallized earlier this year around competing representations of the rape victim who was described by the media as Nirbhaya ('fearless one'), Damini ('lightning'), Amaanat ('treasured possession'), and Delhi's braveheart (Roy 2012).

2 This interrogation of Indian state and society by the protesting publics on India gate illuminates commonplace binaries of state/society, tradition/modern, and liberal/ illiberal. Media narratives presented the Indian state as if it were under siege from 
society at large, thereby accentuating a reified opposition between 'state' and 'society'. The forces that claim to represent 'tradition' and 'modernity', or different traditions and modernities, fought pitched battles in newsrooms, public spaces, and cyberspace. Liberalism and its opposite, too, came to be redefined in terms of one's response to the rapists and the victim, one's preferred form of punishment, and one's suggestions to overhaul the judicial system alongside ruling on the case at hand. As such, the events following the December 16 rape also throw light on the peculiar tropes by which postcolonial selves have typically been expressed in India, whether in the early postcolonial decades or the post-liberalization years. By 'self', as we explain later, we mean the subjective being of human existence, a kind of screen mediating continually between inner psychological impulses and the demands of the external environment. As the Delhi rape case shows, these selves emerge against the backdrop of particular events and processes, and even when we are tempted to rely on timeworn binaries to interpret what unfolds before us, the dominant rubrics through which Indian politics and society are understood fall short. The rubrics of 'identity', interest-group politics, and patronage networks, for example, often speak to a deeply instrumentalist perspective, which reduces politics in India to a basic calculus of costs versus benefits. According to this perspective, the modern state, as the locus of formal institutionalized power, is seen as fostering modern forms of 'identity politics' that propel individual selves to jockey for power and privilege in the public sphere (Brass 1965, 1985, Bailey 1969, Pocock 1973, Gallagher et al. 1973, Wilkinson 2004, Chandra 2004). By contrast, non-instrumental or inner versions of the self, apparently manifest in notions of 'community' and 'culture', are typically imagined as existing outside the formal domains of politics and economy (Nandy 1983, Chatterjee 1993, Chakrabarty 2008). These lifeworlds, whether elite or subaltern, are typically believed to be somehow severed from the rough and tumble of modern democratic politics (see, for example, Nandy 2007). This binary view of state and society, the external and the internal, the instrumental and the non-instrumental, the political and the sociocultural, pervades both academic and lay discourse on politics in postcolonial India. One observes the entrenchment in everyday discourse of these academic binaries, which are subsequently engaged, interrogated, maneuvered, and appropriated by actors in various fields.

\section{Beyond binaries}

3 In this special issue, we seek to acknowledge the analytic role of binaries in understanding politics and society in modern India, yet we seek to build on recent ethnographic work to unsettle these binaries and propose a new framework for studying postcolonial India. For us, the 'political' is an emergent phenomenon that undergirds everyday practices and institutions of popular democracy and associational life. It is emergent because it does not simply follow from what preceded it temporally; a radical contingency is thus built into this conception of the 'political'. As in Chantal Mouffe's (2000) conception of 'agonistic democracy', in which competing interests and allegiances contest each other rather than deliberate and seek consensual arrangements, the 'political' for us is a shifting arena marked by both conflict and cooperation, which makes available myriad routes for individuals to act and express themselves in society. The emergent, shifting nature of political life prevents us from fixing subjectivities to individuals and/or groups in, say, the recent anti-rape protests in metropolitan India. Not 
only is the terrain of politics shifting constantly, but so too are postcolonial selves and their ethical notions. This is partly on account of global geopolitics and neoliberal governance today, but also partly on account of social transformations in postcolonial India and beyond that destabilize the inherited categories used to study democratic politics. As states, markets, social movements, and even schools and families provide contexts in which the self-making processes of different subjects unfold at a given historical juncture, a range of ethical notions from gender equality to communitarian justice are accommodated within the emergent 'political' arena of agonistic democracy. As the old binaries fall by the wayside, we argue, the 'political' in postcolonial India increasingly embraces not only key loci of self-making, but also arrangements within which new ethical codes get crafted.

4 To contextualize our contribution to longstanding debates on Indian politics and society, we do not believe it is necessary to limit ourselves temporally to the early postcolonial decades or the contemporary post-liberalization period. Our task of transcending theoretical binaries and offering a new theoretical framework to study postcolonial politics and society in India does not depend on any particular account of the rise of Hindu nationalism or the unraveling of Nehruvian socialism. In this section, we seek to establish an intellectual-historical context for our theoretical intervention in this special issue. To do so, we begin by acknowledging older modes of conceptualizing what we call 'self-making'. To our mind, self-making in postcolonial India has been studied primarily through the lens of intellectual frameworks that posit an inner/outer distinction in politics and society. The origins of this tendency may be traced arguably to M.K. Gandhi's Hind Swaraj (1997 [1909]), an anti-colonial tract that consciously demarcates the inner domains of the colonized from the external world of the colonizers. Gandhi's political aim of swaraj or self-rule was, of course, a project of ethical self-making above all based on non-violence (ahimsa), neighborliness (mitrata), service (seva) (Skaria 2002). Even as Gandhi (1997 [1909]) expressed his abhorrence for markers of modernity such as courts, railways, and machines, and urged both colonizer and colonized to a natural idyllic state in which individuals tamed their desires and needs, his solution to the violence of capitalist modernity lay not in class struggle but in the fashioning of disciplined selves in mutual harmony with each other in the emerging postcolony (Mantena 2012). Whereas the wealthy would assume trusteeship to care for their poorer brethren, the subaltern classes would, by the same token, abandon revelry and rioting to join in the service of the nation-in-the-making.

5 Although much contemporary political thinking parts ways with Gandhian thought and practice, it is striking how much Indian postcolonial theorists have drawn on the basic binaries that guided Gandhi's vision of social change. Consider, for instance, the writings of Partha Chatterjee (1993) and Sudipta Kaviraj (2005), whose conceptions of postcolonial modernity rest on a shared critique of Eurocentric theories and concepts. Chatterjee (1990), in his critique of Charles Taylor's celebration of 'civil society' (1990), explains that classical liberal oppositions between civil society and the state or between capital and community are immanent to Western modernity, and hence, they cannot simply be replicated in postcolonial contexts. In a similar vein, Sudipta Kaviraj (2001: 309) has argued that 'civil society' in the postcolonial context refers to the formation of a certain kind of liberal-democratic subject after decolonization, a process characterized necessarily by 'imitative enthusiasm' by nationalist elites in India and elsewhere. Claims of universality on behalf of 'civil society' are thus belied by historically contingent 
categories that arose in Enlightenment Europe and their postcolonial variants after the end of five centuries of imperial domination.

In elaborating this comparison between 'our' and 'their' modernity, another binary that dominates postcolonial theory in India is the Gramscian one between civil and political society (Chatterjee 2004, 2011, Srivastava \& Bhattacharya 2012). For Partha Chatterjee, a large section of political consciousness in postcolonial India does not snugly fit into the descriptions of the parlor, market, guild, and church in European narratives of the emergence of modern civil society and the democratic public sphere. Chatterjee argues that the category of 'civil society' emerged through the nationalist elite's engagement since the $19^{\text {th }}$ century with colonial modernity, whereas 'political society' emerged through the engagement of the rest of postcolonial society to 'democracy' after decolonization. 'Civil society' in the postcolony is, for Chatterjee, thus quite different than what has been valorized by liberals and communitarians in the North Atlantic world. He writes (2011: 172):

An important consideration in thinking about the relation between civil society and the state in the modern history of countries such as India is the fact that whereas the legal-bureaucratic apparatus of the state has been able, by the late colonial and certainly in the post-colonial period, to reach as the target of many of its activities virtually all of the population that inhabits its territory, the domain of civil social institutions as conceived above is still restricted to a fairly small section of 'citizens'. This hiatus is extremely significant because it is the mark of non-Western modernity as an always incomplete project of 'modernization' and of the role of an enlightened elite engaged in a pedagogical mission in relation to the rest of society.

It is this 'pedagogical mission' that Chatterjee believes sets postcolonial civil society apart from its Euroamerican counterpart. Postcolonial civil society coexists with 'political society', a shadowy presence beyond modern bourgeois life and the rule of law, albeit with its own distinctive forms of associational life and engagements with the modern state. Political society, a peculiarity of postcolonial life, has four features according to Chatterjee (ibid. 177):

1. Its 'demands on the state are founded on a violation of the law';

2. It demands governmental welfare as a matter of 'right', not on the basis of a liberal register of civil rights;

3. It demands welfare as 'collective rights' of a 'community', even if this community 'is only the product of a recent coming together through the illegal occupation of a particular piece of public land or collective illegal consumption of a public utility'; and

4. State agencies and NGOs deal with it as 'populations' deserving of welfare rather than as a section of the citizenry as defined by the constitution.

Political society may be said to exist in uncertain institutional forms because its members, despite their structural position of marginality, are attuned to the power, practices and logics of the postcolonial state in order to strategically manipulate the promises of the state and capital to their own advantage (Chatterjee 2004). Accordingly, rural protest movements, urban squatting practices, and street vendors' campaigns against zoning laws are three examples of the protean institutional forms that characterize political society. These and other examples of contemporary popular politics in India enable Chatterjee to map out a zone of illegal and paralegal contestations by those who live at the economic and political margins of postcolonial society and grapple with state and non-state agencies as they seek to influence their ways. In these postcolonial contestations, 'civil society' appears incapable of extending its hegemony over the subaltern classes in the manner suggested by the Italian Marxist thinker Antonio 
Gramsci (1971). Instead, 'political society', as it is constituted by the postcolonial subaltern classes, generates its own ways of being and political grammars, which often clash with those of its well-meaning patrons in the state, NGOs, and even academia.

In these theoretical discussions, Chatterjee and Kaviraj are keen to characterize postcolonial selves in ways that are distinct from their Euroamerican counterparts. Postcolonial selves are thus constantly described as traversing the boundaries between capital and community, public and private spheres, and civil and political society. The four papers in this special issue also explore postcolonial self-making in terms of traversing these conceptual boundaries as defined in Western political thought, albeit in a granular and processual manner through ethnographic lenses. These papers show, for instance, the ambivalent pursuits of bourgeois activists and women revolutionaries, the yearnings for and rejection of modern pedagogies of civicness, and strategic conduct by marginal populations who speak back to the postcolonial state in its own language. Yet these papers also reveal the limits of postcolonial theoretical binaries between, say, civil and political society. There is much more to postcolonial self-making than battles for control over the democratic state and the public goods it commands, alignment with or opposition to civil society and corporatized capital, and contrasts with Euroamerican analogues. As recent anthropological studies of politics in India show, democratic statemaking processes and welfarist policies bring about different subject-positions that merit study on their own terms (Sharma 2008, Michelutti 2008, Pandian 2009, Shah 2010, Price \& Ruud 2010, Madsen et al. 2011). Moreover, as other anthropological studies explain, contemporary politics in India cannot be reduced solely to the long-term effects of colonial domination to the extent that regimes such as nationalism, regionalism, neoliberalism, and socialism foster the fashioning of selves in postcolonial India (Bate 2009, Da Costa 2010, Gellner 2010, Nilsen 2010, Baviskar \& Ray 2011, Kunnath 2012). In other words, the study of postcolonial self-making opens up new ways to thinking about Indian politics and society in a fine-grained, close-to-the-ground manner, beyond existing conceptual binaries that overstate the explanatory role of colonialism in explaining postcolonial politics.

10 Through their reliance on the ethnographic method rather than textual criticism or introspection, the papers in this issue cut across familiar binaries between the West and non-West, civil and political society, and even elite and subaltern. An analytical focus on the self-making process is valuable, we argue, insofar as it opens up diverse and counterintuitive modalities of postcolonial being to be studied in their own terms. Such an analytical move offers at least three distinct advantages: firstly, it guards against a kind of 'methodological holism' that simply reads the content of postcolonial selves off macrostructural categories or sociocultural units of belonging; secondly, it avoids reproducing colonial tropes of non-Western Otherness as cultural symbols of postcolonial difference today, especially in the light of growing evidence of the 'modernity of tradition' in postcolonial contexts (Rudolph \& Rudolph 1967, Hobsbawm \& Ranger 1983, Mamdani 1996, Dirks 2001, Mantena 2010); thirdly, it reveals the difficulties inherent in presupposing a watertight separation between bourgeois and subaltern lifeworlds when, in fact, urban middle-class individuals and their subaltern counterparts may actually share much in common when it comes to perspectives, aspirations, strategies for negotiating different regimes of power, interests, and ideology. Attention to both creative forms of individuation as well as the sublimation of social anxieties can, therefore, help us navigate a complex terrain in which identities, ideologies, and structures shape and 
are, in turn, shaped by emergent selves. In this regard, this special issue intends to be theoretically suggestive and, hence, ineluctably preliminary in its formulations. Far from being the final word on this subject, it endeavors to initiate a new conversation on postcolonial politics and society in India and beyond.

\section{Self-making and ethics: What, why, how?}

11 In this special issue, the 'self' denotes the subjective being or lived human existence. It is, in other words, mediating continually between inner psychological impulses and the demands of the external environment. As such, the 'self' is neither wholly intrinsic nor extrinsic to individuals, that is, it straddles any binary opposition between the inner and outer worlds of individuals. The notion of the 'self thus cannot simply be substituted by those of the 'individual' or the 'subject', because an individual or subject is typically constituted by multiple 'selves', each of which connects him or her to different sociocultural milieus or collectives. Moreover, by emphasizing 'self-making', the papers in this issue commit to a processual understanding of the 'self' as an object of study that is constantly in flux. Accordingly, the making and remaking of the 'self' is an ongoing process, and what we observe before us at present ought to be understood as no more than a fleeting glimpse of an object in motion. To the extent that the papers in this issue concern themselves with postcolonial self-making in India, they attend to particular sites and contexts that define as well as circumscribe their analytical frames. However, the overarching theoretical focus of this issue should interest scholars of other postcolonial and even metropolitan contexts insofar as the self and self-making are emerging objects of study worldwide today.

The social scientific literature on the 'self' and 'self-making' is vast enough to prohibit a comprehensive survey of psychological, sociological, anthropological, and philosophical understandings of these terms. Nonetheless, this section briefly sketches the principal intellectual influences on the papers in this issue. Firstly, cognitive and social psychological notions of the 'self' and 'self-making' serve as a baseline understanding of these terms. Psychologists identify the 'self' at the confluence of cognitive ('internalist') and interpersonal ('externalist') aspects of one's being (Baumeister 1999, Baumeister \& Bushman 2013). At the same time, the 'self' is neither the sum total of our neurological reactions to external stimuli nor merely a set of mindless responses to others in society (Kohut 1971, Hewitt \& Shulman 2010). It may be further said, following developmental psychologists, that the 'self' and one's awareness of it evolve over one's lifetime and in particular sociocultural contexts in which one is embedded (Nowak et al. 2000, Spencer \& Sedikides 2007). These insights from psychology are complemented by those from sociology, which offer ways to ground the trajectories of individual selves in what Pierre Bourdieu (1993) famously called social 'fields'. Moreover, these socially grounded selves are engaged in meaning-making activities that bridge the gap between consciousness and action (Yanow \& Schwartz-Shea 2006). Social structures certainly impinge on the self and self-making processes, but the latter cannot simply be read off the former. Indeed, as all four papers in this issue demonstrate, the making of individual selves contributes to the process of 'structuration' (Giddens 1984, Sewell 1992) or the emergence of structures. The making of selves is, in other words, not simply a matter of exercising individual agency, but a micro-process by which new structures replace older ones; by the same token, social 
change is not simply a structural matter, but one in which changes produced at the micro-level of individuals are visible.

13 Anthropological and philosophical accounts of the 'self' and 'self-making' also strongly influence the papers in this issue. In particular, we heed Aihwa Ong's (1996: 737) suggestion to take 'self-making' seriously instead of treating subjectivities as if they are determined wholly by macro-social forces. Equally, we follow recent anthropological works in specifying the precise relationship between the 'self' and citizenship in postcolonial and transnational contexts (Ong 1999, Cruikshank 1999, Lazar 2008, Holston 2008). From the vantage point of this emerging body of anthropological scholarship on India (Sharma 2008, Cody 2009, Pandian 2009, Lukose 2009, Madhok 2013), 'civil society' and 'political society' are much too broad and vague to capture the empirical particularities and nuances of self-making in postcolonial India. It is always necessary to inquire into particular selves in particular spatio-temporal contexts and to locate these selves in a wider sociopolitical canvas. Such detailed empirical inquires do not, however, imply a loss of philosophical rigor. After all, the intimate micro-practices that constitute modern 'technologies of the self' are ultimately linked to macro-structural processes of state formation and social discipline (Michel Foucault 1988, 1997). Hence, anthropological studies of these micro-practices cannot simply be read via narrow empiricist lenses as simply individuation or monolithically as subject-formation, but as emblems of wider social transformations in India and beyond. Indeed, the social performance of these micro-practices of the 'self' and 'self-making' are key sites to study the workings of theoretical abstractions such as power, capital, culture, and gender (Goffman 1959, Butler 1990). The nature of the 'self' and the processes of its making are, therefore, critical to understand what Julia Kristeva (1982) has termed 'abjection', that is, how boundaries between individuals and groups in society come to acquire a salience on both affective and instrumental registers of political life.

These transdisciplinary influences on papers in this special issue sharpen their theoretical focus even as they dwell on subjects as different as middle-class revolutionary women and forest-dwelling Kondh adivasis. In either case, one encounters the limits of old binaries between the inner and outer domains of subcontinental politics, affective and instrumental action, and civil and political society. For middle-class women revolutionaries, one finds how the articulation of gendered political concerns within a class-based social movement leads to peculiar ambivalences and ambiguities for the women themselves. For the Kondhs in highland Orissa, one witnesses how processes of self-making today are surprisingly tied to recent forest rights legislation that offers ways of re-mapping adivasi territories and moulding subjectivities in neoliberal times. In this manner, we urge readers to rethink questions of personality, leadership, calculation, affect, and performativity in terms of postcolonial self-making processes. By focusing on how individuals fashion, perform, and maneuver ideas of community, civicness and citizenship, the papers in this issue interrogate the politics of self-making in postcolonial India. These processes of self-making are made explicit in, for example, the forging of political allegiances and affective stances. Yet these processes are also manifest implicitly in the crafting of political subjectivities through creative acts of individuation and the framing of difference, both of which generate scripts of the self. In this manner, a range of transdisciplinary concerns are brought to bear in this special issue to show how the analytic of 'self-making' can help us move beyond the conventional binaries of postcolonial theory. 

grounded in sociopolitical contexts with distinctive ethical terrains, in which debates and choices of right and wrong become meaningful. For instance, even the usage of 'self' or 'selves' is modern insofar as it connotes a 'radical reflexivity', by which one reflects on one's actions as well as one's subjective experiences (Taylor 1995: 57). More generally, 'selfhood' and 'morality' are, in the philosopher Charles Taylor's (1989: 3) words, 'inextricably intertwined'. Both make sense in tandem with each other against particular 'frameworks' that provide 'backgrounds...for our moral judgments, intuitions, or reactions' (Taylor 1989: 26). The collapse of these 'frameworks' and 'backgrounds' produces the kind of moral crisis that Alasdair MacIntyre (1981:1-22) alleges is peculiar to modern civilization. Whether or to what extent this allegation is true does not concern us here. Our focus is on what MacIntyre (1981: 146-225) understands to be the ethical underpinnings of human selves, whether his Aristotelian 'virtue ethics' or some other moral framework that provides a background to think and act politically in the world. the anthropologist Douglas Rogers (2011) has recently proposed a distinction that is useful for our purposes here. For Rogers (2011: 11-12), 'morality' refers to 'lawlike codes, formal systems or conventions', whereas 'ethics' denotes:

A field of socially located and culturally informed practices that are undertaken with at least somewhat conscious orientation towards conceptions of what is good, proper, or virtuous. These practices are historically situated and play out in an often-competitive arena of partially shared, partially discordant sensibilities. They may be directed at oneself or toward others. They may succeed or fail.

Morality thus concerns frameworks and backgrounds in Taylor's terms; by contrast, ethics is the domain of practices by which human selves become apparent against moral frameworks and backgrounds. As Taylor (1989: 28) puts it:

[t]o know who you are is to be oriented in moral space, a space in which questions arise about what is good or bad, what is worth doing and what not, what has meaning and importance for you and what is trivial and secondary.

Self-making processes must be understood in terms of these moral spaces inhabited by individuals and the frameworks and backgrounds against which they think and act. At the same time, self-making processes reflect as well as shape ethical practices of human selves in a given space and time. The relationship is an intimate one, especially as far as self-making processes go, yet there is a vital distinction between 'morality' and 'ethics' that is worth emphasizing here.

To speak of the politics and ethics of self-making in postcolonial India is to anchor these concepts in a sociohistorical context that is outside the conventional domain of modern social theory, namely, Europe. This is, of course, a matter of 'provincializing Europe' (Chakrabarty 2008): understanding the nature of self-making processes outside Europe, and deploying such understandings to revise existing theories of self and society. Two recent efforts of this kind are noteworthy here. The first is an effort by Anand Pandian and Daud Ali (2010) to map historical and contemporary responses to the fundamental question, 'How ought one to live?' The second is a volume of essays on the ubiquitous yet elusive figure of the 'guru' in South Asia, edited by Jacob Copeman and Aya Ikegama (2012). Both volumes span vast stretches of time and space in South Asia, and both are interested in explaining how ethical ideas and practices in this part of the world are similar to and different from elsewhere, especially Europe. On the surface, the papers in 
this special issue seem to share much in common with these two volumes. Yet the differences are, arguably, more instructive. Firstly, all of the essays in Pandian and Ali (2010) proceed from an unstated assumption of methodological holism. In other words, they assume that 'ethics' is, above all, a cultural affair, and hence, they proceed to characterize entire milieus with broad brushstrokes sans the focus on self-making in this issue. Secondly, Copeman and Ikegama (2012), albeit closer to our focus here, are more concerned with the idiosyncrasies of individual gurus and the diversity of guru-ship in South Asia than with the relationship between self-making processes and social change. From our perspective, questions of 'identity' and 'orientation' cannot be reduced to either cultural norms or individual idiosyncrasies. A focus on the politics and ethics of selfmaking in postcolonial India allows us to navigate the co-constitution of self and society without falling prey to methodological individualism or holism.

\section{Studying selves ethnographically}

In studying selves and self-making processes ethnographically, the papers in this special issue seek to emphasize the processual, interpretive, and fragmentary nature of ethnography as a research method as well as a mode of writing. By 'processual', we mean that the local actors, narratives, and 'social dramas' observed by ethnographers cannot simply be regarded as micro-sociological data, because they are always in conversation with higher social scales and embedded in larger sociohistorical processes (Turner 1957, Moore 1987). A 'grain of sand' may thus be said to offer a glimpse into macro-social processes that are otherwise difficult to study or explain (Wolf 1982, Pachirat 2006). By 'interpretive', we mean that ethnographic data are never merely given but need to be understood via intellectual frames and strategies that continually translate what is observed in terms of what is already known. For Claude Lévi-Strauss (1963), such acts of interpretation presented a challenge of uncovering deep structures of human thought in cultural symbols and patterns. For Clifford Geertz (1973), these interpretive acts were geared towards unpacking layer upon layer of meaning embedded in particular sociocultural contexts. Regardless of one's preferred interpretive lens, there can be little dispute that ethnographic data are subject to researchers' interpretations rather than existing as 'objective' descriptions of social reality. Lastly, by 'fragmentary', we mean that ethnographers cannot claim to describe the social reality of their fieldsites in their entirety, because their position as researchers necessarily leads them to produce partial, contingent knowledge (Clifford 1983, Gupta \& Ferguson 1997). Yet, ethnographic interpretations of social fragments can yield valid social-scientific knowledge of a kind that cannot be generated by more positivistic methods of inquiry (Yanow and SchwartzShea 2006, Schatz 2009). By setting forth our epistemic priors thus, we now intend to highlight the value of ethnography in studying selves and self-making across different scales and sites in postcolonial India.

21 There is already a rich body of ethnographic knowledge on postcolonial selves and selfmaking, to which we seek to contribute in this issue. Well-known works exist, for instance, on colonial legacies in the making of postcolonial selves (Mamdani 1996, Dirks 2001, Mbembe 2001), on remaking postcolonial selves and societies under conditions of 'millennial capitalism' (Comaroff \& Comaroff 2001, Li 2007), on violence and suffering as sites of reorganizing the everyday worlds in which postcolonial self-making processes unfold (Daniel 1996, Kleinman et al. 1997, Das 2007), and on the production of postcolonial 
selves around a politics of piety, moral virtue, bureaucratic indifference or the cultivation of 'traditional' arts (Herzfeld 1997, Mahmood 2005, Weidman 2006, Pandian 2009). These selves emerge in the play of insides and outsides, distances and proximities, modernities and traditions. As in the abovementioned works, the protagonists of the ethnographic narratives in this special issue straddle the conventional binaries of postcolonial theory in India. The maneuvers and stances of these protagonists enable them to negotiate disparate domains of politics and society creatively and contingently. The dominant analytics of 'our' and 'their' modernity or 'political society' versus 'civil society' are rather blunt in apprehending the nuanced and emergent nature of the 'political' as postcolonial Indian selves are made and remade. This is why we plead the case for ethnographic exploration here and place ourselves in a wider intellectual context of ethnographic scholarship on postcolonial politics.

In studying postcolonial Indian selves ethnographically, the papers in this issue claim kinship with older and more recent classics of South Asian anthropology, though they do not necessarily use our conceptual vocabulary of 'self' and 'self-making'. Among older works, we draw inspiration, in particular, from the pioneering work of fieldworkers such as F.G. Bailey (1957) and David Pocock (1973), who carefully sifted through the local meanings of caste, tribe, and social power in Orissa and Gujarat respectively. Among recent works, we align ourselves with critical ethnographic studies of bureaucratic and police officials (Gupta 2012, Jauregui 2013), women and development (Karim 2011, Madhok 2013), misdirected activism and advocacy (Jalais 2010, Shah 2010), and youth politics (Lukose 2009, Jeffrey 2010). In these works, we encounter postcolonial selves grappling with the disparate pulls of state and capital, tradition and modernity, and selfinterestedness and selflessness. Their responses vary from narrating oral histories from the margins of the nation to adopting the languages of governmentality, and from organized resistance to the forces of modernization to staking claim to postcolonial democracy as political entrepreneurs on the stage of electoral politics. Taken together, these older and more recent classics of South Asian anthropology suggest new ways to theorize postcolonial politics in this region beyond the conventional binaries that dominate social scientific thinking on India. We, too, venture on this path beyond the outmoded oppositions between individuals and collectives, state and community, and politics and ethics, in order to develop a new conceptual vocabulary as well as lenses for ethnographers studying postcolonial South Asia.

The four papers in this special issue examine the politics and ethics of self-making making in a range of unconventional settings in postcolonial India. Atreyee Majumder describes her encounters with prominent figures on a rural-urban corridor of Howrah, West Bengal who appropriate and rework the past to craft their public selves. These figures present themselves as individuals in pursuit of 'civic humanism', a modern ideal that seeks to transcend the mundane, even profane, everyday worlds of democratic politics. Lipika Kamra introduces us to the writings of Naxalite women from West Bengal and Kerala to discuss how the party-led quest for revolutionary social change shapes and is, in turn, shaped by the emergent political subjectivities of female comrades. At the same time, these Naxalite women seek to articulate notions of womanhood and autonomy, sometimes in line with party directives and sometimes in opposition to them. Uday Chandra bridges the apparently separate lifeworlds of middle-class and subaltern selves by showing how activists championing 'indigenous' peoples' rights struggle to articulate radical bourgeois selves in the face of rejection by those they claim to 
represent. The myriad aspirations of these well-intentioned activists coalesce around local meanings of 'indigeneity' in contemporary Jharkhand even as the intended beneficiaries of their work seek out new modes of self-expression. Matthew Shutzer turns to the sociocultural worlds of Kondh adivasis in rural western Orissa, and counterintuitively, finds that adivasi 'identity' is defined there in dialogue with new legal regimes inaugurated by the Forest Rights Act (2005). Exercises in mapping forests turns out to be key sites of self-making in these margins of modern India. In all of the papers, selves and self-making are delineated in complex geographies involving the welfare state, revolutionary politics, social ecology, and democratic ideas and institutions. In this manner, these papers speak to the theoretical framework developed in this outline by transcending the usual binaries that dominate the study of South Asian politics and society and outlining more textured understandings of the everyday lives of individuals and collectives in postcolonial India. If readers find in these efforts the kernel of a new approach to studying postcolonial politics in India and beyond, we shall deem our aims fulfilled.

\section{BIBLIOGRAPHY}

Bailey, Frederick G. (1957) Caste and the Economic Frontier, Manchester: Manchester University Press.

Bailey, Frederick G. (1969) Strategems and Spoils: A Social Anthropology of Politics, New York: Schocken Books.

Bate, Bernard (2009) Tamil Oratory and the Dravidian Aesthetic: Democratic Practice in South India, New York: Columbia University Press.

Baumeister, Roy F. (ed.) (1999) Self in Social Psychology: Key Readings, Philadelphia: Psychology Press.

Bate, Bernard; Brad J. Bushman (2013) Social Psychology and Human Nature, Belmont: Cengage Learning.

Baviskar, Amita; Ray, Raka (eds.) (2011) Elite and Everyman: The Cultural Politics of the Indian Middle Classes, New Delhi: Routledge.

Bourdieu, Pierre (1993) The Field of Cultural Production: Essays on Art and Literature, New York: Columbia University Press.

Brass, Paul (1965) Factional Politics in an Indian State: the Congress Party in Uttar Pradesh, Berkeley: University of California Press.

Brass, Paul R. (1985) Ethnic Groups and the State, Totowa: Barnes \& Noble Books.

Butler, Judith (1990) Gender Trouble: Feminism and the Subversion of Identity, New York: Routledge.

Chakrabarty, Dipesh (2008) Provincializing Europe: Postcolonial Thought and Historical Difference, Princeton: Princeton University Press. 
Chandra, Kanchan (2004) Why Ethnic Parties Succeed: Patronage and Ethnic Head Counts in India, New York: Cambridge University Press.

Chatterjee, Partha (1990) ‘A Response to Taylor's 'Modes of Civil Society”, Public Culture 3(1), pp. $119-32$.

Chatterjee, Partha (1993) The Nation and Its Fragments: Colonial and Postcolonial Histories, Princeton: Princeton University Press.

Chatterjee, Partha (2011) Lineages of Political Society: Studies in Postcolonial Democracy, New York: Columbia University Press.

Chatterjee, Partha (2004) The Politics of the Governed: Reflections on Popular Politics in Most of the World, New York: Columbia University Press.

Chatterjee, Partha (2012) 'After Subaltern Studies', Economic and Political Weekly, 47(35), pp. 44-49.

Clifford, James (1983) ‘On ethnographic authority’, Representations, 1/2, pp. 118-46.

Cody, Francis (2009) 'Inscribing Subjects to Citizenship: Petitions, Literacy Activism, and the Performativity of Signature in Rural Tamil India', Cultural Anthropology, 24 (3), pp. 347-80.

Comaroff, Jean; Comaroff, John L. (2001) Millennial Capitalism and the Culture of Neoliberalism, Durham: Duke University Press.

Copeman, Jacob; Ikegama, Aya (eds.) (2012) The Guru: New Interdisciplinary Perspectives, London and New York: Routledge.

Cruikshank, Barbara (1999) The Will to Empower: Democratic Citizens and Other Subjects, Ithaca: Cornell University Press.

Da Costa, Dia (2009) Development Dramas: Reimagining Rural Political Action in Eastern India, New Delhi: Routledge.

Daniel, Valentine E. (1996) Charred Lullabies: Chapters in an Anthropography of Violence, Princeton: Princeton University Press.

Das, Veena (2007) Life and Words: Violence and the Descent into the Ordinary, Berkeley: University of California Press.

Dirks, Nicholas B. (2001) Castes of Mind: Colonialism and the Making of Modern India, Princeton: Princeton University Press.

Foucault, Michel (1988) The History of Sexuality, 3 vols., New York: Vintage Books.

Foucault, Michel (1997) Ethics: Subjectivity and Truth, edited by Paul Rabinow, New York: New Press.

Gallagher, John A.; Seal, Anil; Johnson, Gordon (eds.) (1973) Locality, Province and Nation: Essays on Indian Politics 1870 to 1940, Cambridge: Cambridge University Press.

Gandhi, Mohandas K. (1997) Hind Swaraj and other Writings, (edited by Anthony J. Parel), Cambridge: Cambridge University Press.

Geertz, Clifford (1973) Interpretation of Cultures, New York: Basic Books.

Gellner, David N. (ed.) (2010) Varieties of Activist Experience: Civil Society in South Asia, New Delhi: Sage Publications.

Giddens, Anthony (1984) The Constitution of Society: Introduction of the Theory of Structuration, Berkeley: University of California Press. 
Gramsci, Antonio (1971) Selections from the Prison Notebooks, (Transl. by Quentin Hoare \& Geoffrey Nowell-Smith), New York: International Publishers.

Goffman, Erving (1959) The Presentation of Self in Everyday Life, Garden City: Doubleday. Gupta, Akhil (2012) Red Tape: Bureaucracy, Structural Violence, and Poverty in India, Durham: Duke University Press.

Gupta, Akhil; James Ferguson (1997) 'Discipline and Practice: 'The Field' as Site, Method, and Location in Anthropology', in Akhil Gupta \& James Ferguson (eds.), Anthropological Locations: Boundaries and Grounds of a Field Science, Berkeley: University of California Press, pp. 1-46.

Herzfeld, Michael (1993) The Social Production of Indifference: Exploring the Symbolic Roots of Western Bureaucracy, Chicago: University of Chicago Press.

Hewitt, John P.; Shulman, David (2010) Self and Society: A Symbolic Interactionist Social Psychology, Boston: Allyn \& Bacon.

Hobsbawm, Eric J.; Ranger, Terence O. (eds.) (1983) The Invention of Tradition, Cambridge: Cambridge University Press.

Holston James (2008) Insurgent Citizenship: Disjunctions of Democracy and Modernity in Brazil, Princeton: Princeton University Press.

Jalais, Annu (2010) Forest of Tigers: People, Politics and Environment in the Sundarbans, New Delhi: Routledge.

Jauregui, Beatrice (2013) 'Beatings, Beacons, and Big Men: Police Disempowerment and Delegitimation in India', Law and Social Inquiry, 38(3), pp. 643-69.

Jeffrey, Craig (2010) Timepass: Youth, Class and the Politics of Waiting in India, Stanford: Stanford University Press.

Karim, Lamia (2011) Microfinance and its Discontents: Women in Debt in Bangladesh, Minneapolis: University of Minnesota Press.

Kaviraj, Sudipta (2005) 'An Outline of a Revisionist Theory of Modernity', European Journal of Sociology, 46(3), pp. 497-526.

Kaviraj, Sudipta (2001) 'In Search of Civil Society', in Sudipta Kaviraj \& Sunil Khilnani (eds.), Civil Society: History and Possibilities, Cambridge: Cambridge University Press, pp. 287-323.

Kleinman, Arthur; Das, Veena; Lock, Margaret (eds.) (1997) Social Suffering, Berkeley: University of California Press.

Kristeva, Julia (1982) Powers of Horror: An Essay on Abjection, New York: Columbia University Press. Kohut, Heinz (1971) The Analysis of the Self, New York: International Universities Press.

Kunnath, George J. (2012) Rebels from the Mud Houses: Dalits and the Making of the Maoist Revolution in Bihar, New Delhi: Social Science Press.

Lazar, Sian (2008) El Alto, Rebel City: Self and Citizenship in Andean Bolivia, Durham: Duke University Press.

Lévi-Strauss, Claude (1963) Structural Anthropology, 2 vols., New York: Basic Books.

Li, Tania M. (2007) The Will to Improve: Governmentality, Development, and the Practice of Politics, Durham: Duke University Press.

Lukose, Ritty A. (2009) Liberalization's Children: Gender, Youth, and Consumer Citizenship in Globalizing India, Durham: Duke University Press. 
MacIntyre, Alasdair (1981) After Virtue: A Study in Moral Theory, Notre Dame: University of Notre Dame Press.

Madhok, Sumi (2013) Rethinking Agency: Developmentalism, Gender and Rights, New Delhi: Routledge.

Madsen, Stig T.; Nielsen, Kenneth B.; Skoda, Uwe (eds.) (2011). Trysts with Democracy: Political Practice in South Asia, London: Anthem Press.

Mahmood, Saba (2005) Politics of Piety: The Islamic Revival and the Feminist Subject, Princeton: Princeton University Press.

Mamdani, Mahmood (1996) Citizen and Subject: Contemporary Africa and the Legacy of Late Colonialism , Princeton: Princeton University Press.

Mani, Lata (1988) Contentious Traditions: The Debate on Sati in Colonial India, Berkeley: University of California Press.

Mantena, Karuna (2012) ‘Another Realism: The Politics of Gandhian Nonviolence', American Political Science Review, 106(2), pp. 455-70.

Mantena, Karuna (2010) Alibis of Empire: Henry Maine and the Ends of Liberal Imperialism, Princeton: Princeton University Press.

Mbembe, Achille (2001) On the Postcolony, Berkeley: University of California Press.

Michelutti, Lucia (2008) The Vernacularisation of Democracy: Politics, Caste, and Religion in India, London: Routledge.

Moore, Sally F. (1987) 'Explaining the Present: Theoretical Dilemmas in Processual Ethnography', American Ethnologist, 14(4), pp. 727-36.

Mouffe, Chantal (2000) The Democratic Paradox, London and New York: Verso.

Nandy, Ashis (2007) The Romance of the State and the Fate of Dissent in the Tropics, New Delhi: Oxford University Press.

Nandy, Ashis (1983) The Intimate Enemy: Loss and Recovery of Self under Colonialism, New Delhi: Oxford University Press.

Nilsen, Alf G. (2010) Dispossession and Resistance in India: The River and the Rage, London and New York: Routledge.

Nowak, Andrzej; Vallacher, Robin R.; Tesser, Abraham; Borkowski, Wojciech (2000) 'Society of Self: The Emergence of Collective Properties of Self-Structure', Psychological Review, 107(1), pp. 39-61.

Ong Aihwa (1999) Flexible Citizenship. The Cultural Logics of Transnationality, Durham: Duke University Press.

Ong Aihwa (1996) 'Cultural Citizenship as Subject-making: Immigrants Negotiate Racial and Cultural Boundaries in the United States,' Current Anthropology, 37 (5), pp. 737-62.

Pachirat, Timothy (2006) 'We Call It a Grain of Sand: The Interpretive Orientation and a Human Social Science', in Dvora Yanow \& Peregrine Schwartz-Shea (eds.), Interpretation and Method: Empirical Research Methods and the Interpretive Turn, New York: M.E. Sharpe, pp. 373-79.

Pandian, Anand; Ali, Daud (eds.) (2010) Ethical Life in South Asia, Bloomington and Indianapolis: University of Indiana Press.

Pandian, Anand (2009) Crooked Stalks: Cultivating Virtue in South India, Durham: Duke University Press. 
Pocock, David F. (1973) Mind, Body and Wealth: A Study of Belief and Practice in an Indian Village, Oxford: Basil Blackwell.

Rogers, Douglas (2011) The Old Faith and the Russian Land: A Historical Ethnography of Ethics in the Urals, Ithaca: Cornell University Press.

Roy, Sandip (2012) ‘Why does Media want to give Delhi Gangrape Victim a Name?' First Post, December 24, URL: http://www.firstpost.com/living/why-does-media-want-to-givedelhigangrape-victim-a-name-567444.html?utm_source=ref_article.

Rudolph, Lloyd I.; Susanne H. Rudolph (1967) The Modernity of Tradition: Political Development in India, Chicago: University of Chicago Press.

Ruud, Arild E.; Price, Pamela G. (2010) Power and Influence in India: Bosses, Lords and Captains, New Delhi: Routledge.

Sewell, William H. (1992) 'A Theory of Structure: Duality, Agency, and Transformation', The American Journal of Sociology, 98(1), pp. 1-29.

Schatz, Edward (ed.) (2009) Political Ethnography: What Immersion Contributes to the Study of Power, Chicago: University of Chicago Press.

Shah, Alpa (2010) In the Shadows of the State: Indigenous Politics, Environmentalism and Insurgency in Jharkhand, India, Durham: Duke University Press.

Sharma, Aradhana (2008) Logics of Empowerment: Development, Gender, and Governance in Neoliberal India, Minneapolis: University of Minneapolis Press.

Skaria, Ajay (2002) 'Gandhi’s Politics: Liberalism and the Question of the Ashram', South Atlantic Quarterly 101 (4), pp. 955-86.

Spencer, Steven J.; Sedikides, Constantine (eds.) (2007) The Self, Philadelphia: Psychology Press. Srivastava, Neelam; Bhattacharya, Baidik (eds.) (2012) The Postcolonial Gramsci, New York: Routledge.

Taylor, Charles (1989) Sources of the Self: Making of the Modern Identity, Cambridge: Cambridge University Press.

Taylor, Charles (1990) ‘Modes of Civil Society', Public Culture, 3(1), pp. 95-117.

Taylor, Charles (1995) 'The Dialogical Self', in Robert F. Goodman \& Walter R. Fischer (eds.), Rethinking Knowledge: Reflections across Disciplines. Albany: SUNY Press, pp. 57-68.

The Times of India. 2013. 'Rapes occur in India, not Bharat: RSS supremo Bhagwat', January 4.

Turner, Victor W. (1957) Schism and Continuity in an African Society: A Study of Ndembu Village Life, Manchester: Rhodes-Livingstone Institute.

Weidman, Amanda J. (2006) Singing the Classical, Voicing the Modern: The Postcolonial Politics of Music in South India, Durham: Duke University Press.

Wilkinson, Steven I. (2004) Votes and Violence: Electoral Competition and Ethnic Riots in India, New York: Cambridge University Press.

Wolf, Eric R. (1982) Europe and the People without History, Berkeley: University of California Press.

Yanow, Dvora; Schwartz-Shea, Peregrine (eds.) (2006) Interpretation and Method: Empirical Research Methods and the Interpretive Turn, New York: M.E. Sharpe. 


\section{AUTHORS}

\section{UDAY CHANDRA}

Research fellow, Max Planck Institute for the Study of Religious and Ethnic Diversity, Göttingen

\section{ATREYEE MAJUMDER}

$\mathrm{PhD}$ candidate in political and historical anthropology at Yale University 